\title{
Studi Keragaman Genetik Dua Puluh Galur Inbred Jagung Manis Generasi $\mathbf{S}_{7}$
}

\section{Morphological Genetic Variations of Twenty Sweet Corn Inbred Lines $S_{7}$ Generations}

\author{
Purwito Djoko Yuwono, Rudi Hari Murti ${ }^{*}$ Panjisakti Basunanda \\ Fakultas Pertanian Universitas Gadjah Mada,Yogyakarta \\ "email: rhmurti@ugm.ac.id
}

\begin{abstract}
The genetic diversity is basic need of plant breeding. The experiment aimed to evaluate the genetic diversity of twenty sweet corn inbred lines, to estimate broad sense heritability, genetic correlation and path analysis, and grouping the sweet corn inbred lines. Randomized complete block design was used with three replications. ANOVA, genetic correlations, and cluster analysis were used to analysis the data. The genetic diversity coefficients was indicate the high genetic diversity, that was potential for hybrid sweet corn breeding programs. Most characters had high broad sense heritability. The ear weight has a significantly positive correlation with plant height, ear height, number of seed rows, ear length and ear diameter. The ear length and ear diameter have a high direct influence on the ear weight. Cluster analysis grouped the inbred lines into three groups at $70 \%$ similarity coefficient level. The group which have the lowest similarity coefficient level indicated wide genetic distance. The wide genetic distance groups can be used as a parents for composing of hybrids with high level of heterosis.
\end{abstract}

Keywords: Genetic Variations, Inbred Lines, Relationship, Sweet Corn.

\section{INTISARI}

Penelitian ini mengevaluasi keragaman genetik dua puluh galur inbred jagung manis populasi $\mathrm{S}_{7}$. Tujuan penelitian ini adalah untuk mendapatkan informasi keragaman genetik dua puluh galur inbred, heritabilitas dalam arti luas, korelasi genetik dan analisis lintasan, dan jarak genetik antar galur inbred jagung manis. Percobaan lapangan menggunakan rancangan acak kelompok lengkap dengan perlakuan dua puluh galur inbred dan tiga ulangan. Analisis data menggunakan ANOVA, korelasi genetik, dan analisis klaster. Koefisien keragaman genetik yang diperoleh mengindikasikan adanya keragaman genetik antar galur yang diuji. Heritabilitas menunjukkan nilai yang tinggi pada semua variabel kecuali jumlah baris biji. Karakter panjang tongkol dan diameter tongkol memiliki korelasi dan pengaruh langsung yang tinggi terhadap bobot tongkol. Analisis klaster menghasilkan tiga kelompok pada nilai koefisien similarity $70 \%$. Kelompok yang memiliki koefisien similarity paling rendah memiliki jarak genetik terjauh dan dianjurkan sebagai tetua untuk pembuatan hibrida dengan heterosis tinggi.

Kata kunci: Galur Inbred, Jagung Manis, Korelasi, Keragaman Genetik.

\section{PENDAHULUAN}

Peningkatan produksi jagung manis saat ini menunjukan trend yang positif karena memiliki keuntungan ekonomi yang tinggi (Saleh et al., 2001). Produksi jagung manis di Indonesia pada tahun 2014 sebesar 57 juta ton dengan luas panen 3.838.015 ha (Kementan, 2015). Produktivitas jagung manis 15 ton/ha belum dapat mencukupi kebutuhan konsumsi dalam negeri yang mencapai 200 juta ton/tahun (BPS, 2015). Penelitian
Rifianto (2013) menyebutkan bahwa rata-rata produktivitas jagung manis non-hibrida hanya mencapai 12 ton/ha, yang lebih rendah daripada produktivitas nasional. Salah satu langkah penting untuk peningkatan hasil jagung manis adalah dengan pengembangan kultivar hibrida jagung manis berdaya hasil tinggi (Kashiani et al., 2010). Potensi hasil jagung manis hibrida $F_{1}$ mencapai 17-23 ton/ha (Iriany et al., 2011; Rifianto et al. 2013; Sujiprihati et al., 2014). 
Hibrida yang berpotensi hasil tinggi dihasilkan dari pasangan galur inbred dari populasi yang memiliki kelompok heterotik yang berbeda (Pabendon et al. 2007). Persilangan antara tetua yang memiliki latar belakang genetik yang jauh menghasilkan keturunan hibrida $F_{1}$ yang mempunyai nilai heterosis tinggi dibandingkan tetua yang memiliki latar belakang genetiknya dekat (Ruswandi et al., 2006). Stoskopf et al. (1993) menjelaskan bahwa galur inbred dihasilkan setelah melalui proses silang dalam (selfing) dan seleksi untuk karakter yang diinginkan selama lima sampai tujuh generasi.

Keragaman genetik yang luas antar galur inbred memiliki peranan yang besar dalam keberhasilan pemuliaan jagung manis hibrida. Nilai koefisien keragaman genetik, heritabilitas dan korelasi menjadi informasi penting dalam pemuliaan (Saleh et al., 2002a). Luasnya keragaman genetik biasanya dilihat dari nilai koefisien keragaman genetik (KKG) (Pinaria et al., 1995), sedangkan heritabilitas menunjukkan besarnya peran faktor genetik terhadap keragaman fenotipe (Sleper and Poehlman, 2006). Korelasi dan koefisien lintas dapat digunakan untuk mempertimbangkan karakter yang akan diseleksi (Kashiani et al., 2008).

Penelitian ini bertujuan untuk menduga keragaman genetik dan menduga heritabilitas dalam arti luas, korelasi genetik dan analisis lintasan antar karakter, dan mengelompokkan dua puluh galur inbred jagung manis generasi $S_{7}$.

\section{METODOLOGI PENELITIAN}

Penelitian dilaksanakan pada bulan September-Desember 2014 di Desa Pleret, Banguntapan, Bantul, DIY. Bahan tanaman yang digunakan adalah 20 galur inbred jagung manis generasi $\mathrm{S}_{7}$ milik PT Agro Nusantara Prima, sebagai berikut:

Tabel 1. Galur-galur inbred jagung manis

\begin{tabular}{cl} 
Kode & \multicolumn{1}{c}{ Galur Inbred } \\
\hline A & AN 6/15-8-6-1/2-1/4-1/1-1/5 \\
B & AN 4/5-10-8-1/4-1/3-1/1-1/1 \\
C & AN 6/6-9-17-1/2-1/1-1/2-1/6 \\
D & AN 6/6-9-17-1/4-1/1-1/2-1/3 \\
E & AN 6/6-9-17-1/4-1/1-1/2-1/8 \\
F & AN 6/6-9-17-1/4-1/1-1/2-1/10 \\
G & AN 13/1-7-20-1/1-1/1-1/2-1/1 \\
H & AN 13/1-7-20-1/1-1/1-1/3-1/1 \\
I & AN 6/6-9-21-1/6-1/3-1/1-1/3 \\
J & AN 4/5-10-26-1/1-1/2-1/3-1/3 \\
K & AN 4/5-10-26-1/1-1/2-1/3-1/4 \\
L & AN 4/5-10-27-1/2-1/1-1/1-1/2 \\
M & AN 4/5-10-27-1/2-1/1-1/1-1/4 \\
N & AN 7/4-4-29-1/1-1/1-1/2-1/2 \\
O & AN 7/4-4-29-1/1-1/1-1/2-1/5 \\
P & AN 7/4-4-29-1/1-1/1-1/2-1/6 \\
Q & AN 13/1/1-7/1-3/4-1/3-2/5 \\
R & AN 7/4-4-29-1/1-1/1-1/2-1/1 \\
S & AN 6/6-9-17-1/4-1/1-1/2-1/4 \\
T & AN 7/4/3-5/1-2/2-1/3-1/4-2/3 \\
\hline
\end{tabular}

Percobaan menggunakan rancangan acak kelompok lengkap (RAKL) dengan tiga ulangan.
Lahan yang sudah diolah dan diratakan kemudian dibagi menjadi tiga ulangan. Tiap ulangan terdiri 
atas 20 unit percobaan. Setiap unit percobaan terdiri atas tiga baris dan 15 tanaman tiap baris dengan jarak tanam $80 \mathrm{~cm} \times 25 \mathrm{~cm}$, sehingga terdapat 45 tanaman dalam tiga baris. Tanaman dipupuk lima hari setelah tanam (HST) dengan pupuk urea $150 \mathrm{~kg} / \mathrm{ha}$ (setengah dosis urea) dan pupuk NPK $150 \mathrm{~kg} / \mathrm{ha}$ (setengah dosis NPK). Pupuk diberikan diantara tanaman. Pengendalian hama menggunakan pestisida berbahan aktif karbofuran $^{\circledR} \pm 5$ butir per lubang tanam saat penanaman.

Pemeliharaan tanaman meliputi pengairan, penjarangan, pembumbunan, pengendalian gulma, dan pengendalian hama serta penyakit. Pengairan dua kali setiap minggu dengan cara menggenangi parit-parit yang terletak di antara petak-petak percobaan. Pengendalian gulma dilakukan secara manual. Tanaman dibumbun pada saat tiga MST. Pemupukan kedua yaitu pemberian setengah dosis pupuk urea dan NPK dilakukan saat tanaman berumur empat MST dengan cara yang sama seperti pada pemupukan pertama. Pemanenan dilakukan pada saat tongkol jagung sudah terisi sempurna ditandai oleh rambut tongkol yang sudah berwarna coklat kehitaman dan mengering (18 - 22 hari setelah penyerbukan atau sekitar 68 - 72 HST).

Pengamatan dilakukan dengan mengambil tiga tanaman sampel (kecuali umur berbunga jantan dan betina) dalam setiap satuan percobaan. Umur berbunga jantan dan betina ditentukan ketika 50\% bunga jantan anthesis dan 50\% bunga betina reseptif. Karakter yang diamati adalah tinggi tanaman $(\mathrm{cm})$, tinggi tongkol $(\mathrm{cm})$, umur berbunga jantan (HST), umur berbunga betina (HST), bobot tongkol $(\mathrm{g})$, panjang tongkol $(\mathrm{cm})$, diameter tongkol (mm), jumlah baris biji per tongkol, jumlah biji per baris, kadar Padatan Total Terlarut (PTT) $\left({ }^{\circ}\right.$ Brix).

Analisis data dilakukan menggunakan ANOVA dengan SAS 9.3 for Windows ${ }^{\circledR} 64$ bit. Karakter kuantitatif yang diamati pada tiap galur inbred dianalisis ragam menggunakan uji $F$. Pendugaan nilai KKG, heritabilitas arti luas $\left(\mathrm{h}^{2}{ }_{\mathrm{bs}}\right)$, korelasi genetik, dan analisis lintasan dilakukan dari hasil komponen ragam (Tabel 2).

Tabel 2. Sumber keragaman dan nilai harapan

\begin{tabular}{llcl}
\hline Sumber keragaman & Derajat bebas & Kuadrat tengah & \multicolumn{1}{c}{ Nilai harapan } \\
\hline Blok & $\mathrm{r}-1$ & - & - \\
Genotipe & $\mathrm{g}-1$ & $\mathrm{KT}_{\mathrm{G}}$ & $\sigma_{\mathrm{e}}^{2}+\mathrm{r} \sigma_{\mathrm{g}}^{2}$ \\
Galat & $(\mathrm{r}-1)(\mathrm{g}-1)$ & $\mathrm{KT}_{\mathrm{E}}$ & $\sigma_{\mathrm{e}}^{2}$ \\
\hline Total & $\mathrm{g} . \mathrm{t}-1$ & & \\
\hline
\end{tabular}

Berdasarkan analisis ragam, perhitungan nilai ragam lingkungan $\left(\sigma_{\mathrm{Ex}}^{2}\right)$, ragam genotipe $\left(\sigma_{\mathrm{Gx}}^{2}\right)$, ragam fenotipe $\left(\sigma_{\mathrm{Px}}^{2}\right)$ dan koefisien keragaman geneti $(\mathrm{KKG})$ diduga menggunakan persamaan sebagai berikut:

$$
\begin{array}{ll}
\sigma_{\mathrm{Ex}}^{2}=\mathrm{KT}_{\mathrm{Ex}} & \sigma_{\mathrm{Gx}}^{2}=\frac{K T_{G x}-K T_{E x}}{r} \\
\sigma_{\mathrm{Px}}^{2}=\sigma_{G x}^{2}+\frac{\sigma_{E x}^{2}}{r} & \mathrm{KKG}=\frac{\sqrt{\sigma_{G x}^{2}}}{\bar{x}} \times 100 \%
\end{array}
$$

Luas atau sempitnya nilai keragaman genetik suatu karakter ditentukan berdasarkan ragam genetik dan simpangan baku ragam genetik menurut rumus berikut (Pinaria et al. 1995) :

$$
\sigma_{\sigma \mathrm{Gx}}^{2}=\sqrt{\frac{2}{r^{2}}\left[\frac{K T_{G x}^{2}}{d b_{G}+2}+\frac{K T_{E x}^{2}}{d b_{E}+2}\right]}
$$

Apabila $\sigma_{G x}^{2}>2 \sigma_{\sigma \mathrm{Gx}}^{2}$ menunjukkan nilai keragaman genetiknya luas, sedangkan $\sigma_{\mathrm{Gx}}^{2}<2$ $\sigma_{\sigma \mathrm{Gx}}^{2}$ menunjukkan nilai keragaman genetiknya sempit.

Nilai heritabilitas dalam arti luas diduga dengan persamaan (Singh dan Chaudary, 1985) :

$$
\mathrm{h}_{\mathrm{bs}}^{2}=\frac{\sigma_{G x}^{2}}{\sigma_{P x}^{2}} \times 100 \%
$$

Klasifikasi nilai heritabilitas ditetapkan sebagai berikut : rendah $\left(\mathrm{h}^{2}\right.$ bs $\left.\leq 20 \%\right)$, sedang $\left(20 \%<\mathrm{h}^{2}\right.$ bs $\left.\leq 50 \%\right)$ dan tinggi $\left(\mathrm{h}^{2}{ }_{\text {bs }}>50 \%\right)$ (Bahar dan Zen 1993).

Keerataan hubungan setiap karakter dengan karakter bobot dianalisis menggunakan korelasi genetik sebagai berikut:

$$
\mathrm{r}_{\mathrm{G} .(\mathrm{xy})}=\frac{\operatorname{Cov}_{G(x y)}}{\sqrt{\left(\sigma_{G x}^{2}\right)\left(\sigma_{G y}^{2}\right)}}
$$

Keterangan:

$\mathrm{r}_{\mathrm{G}(\mathrm{xy})} \quad=$ koefisien korelasi genetik peubah $\mathrm{x}$ dan $\mathrm{y}$

$\operatorname{Cov}_{\mathrm{G}(\mathrm{x}, \mathrm{y})}=$ peragam $\operatorname{karakter} \mathrm{x}$ dan $\mathrm{y}$

$\sigma_{\mathrm{GX}}^{2} \quad=$ ragam karakter $\mathrm{x}$

$\sigma_{\text {Gy }}^{2} \quad=$ ragam karakter $\mathrm{y}$ 
Kemudian dilanjutkan dengan analisis lintasan (path analysis) berdasarkan persamaan simultan sebagai berikut (Singh dan Chaudhary, 1985) :

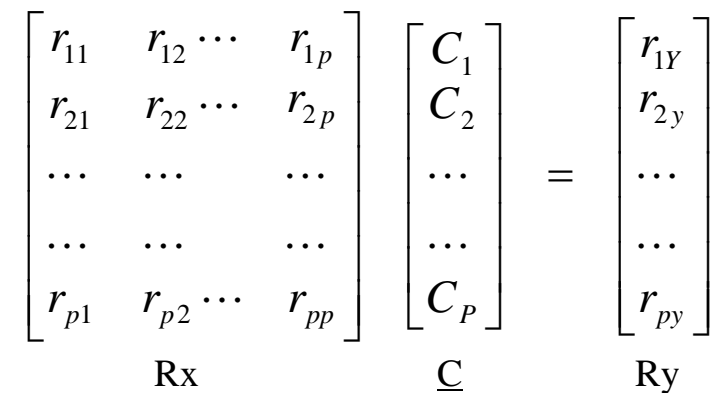

Berdasarkan persamaan di atas, nilai $\underline{\mathrm{C}}$ dapat dihitung menggunakan rumus:

Keterangan :

$$
\underline{\mathrm{C}}=\mathrm{Rx}^{-1} \mathrm{Ry}
$$

$\mathrm{Rx}=$ matriks korelasi antar peubah bebas

$\mathrm{Rx}^{-1}=$ Invers matriks $\mathrm{Rx}$

$\underline{\mathrm{C}}=$ vektor koefisien lintasan yang menunjukkan pengaruh langsung setiap peubah bebas yang telah dibakukan terhadap peubah tak bebas

Ry $=$ vektor koefisien korelasi antara peubah bebas Xi $(i=1,2, \ldots . . p)$ dengan peubah tak bebas $\mathrm{Y}$

Pola pengelompokan dan keragaman antar galur inbred diperoleh berdasarkan data karakter kuantitatif dianalisis menggunakan analisis klaster menggunakan software Minitab ${ }^{\circledR}$. Informasi tentang hubungan kekerabatan akan digunakan sebagai dasar dalam rekomendasi tetua yang akan digunakan dalam pembentukan hibrida.

\section{HASIL DAN PEMBAHASAN}

Hasil analisis ragam dan koefisien keragaman genetik menunjukkan beda nyata dan keragaman genetik yang luas untuk seluruh karakter pada galur-galur inbred, kecuali jumlah baris biji (Tabel 3). Keragaman genetik yang luas antar galur-galur inbred tersebut dapat meningkatkan potensi genetik karakter dari hasil persilangannya (Hallauer et al., 2010) sehingga dapat dimanfaatkan untuk program pemuliaan jagung manis hibrida (Rifianto et al., 2013).

Penduga nilai ragam genotipe, ragam fenotipe dan heritabilitas arti luas untuk hasil dan komponen hasil galur-galur inbred jagung manis terdapat pada Tabel 3. Seluruh karakter memiliki nilai heritabilitas arti luas yang tinggi kecuali jumlah baris biji. Hal ini menunjukkan bahwa keragaman karakter pada galur-galur inbred sangat dipengaruhi faktor genetik. Hasil penelitian ini sejalan dengan Kashiani et al. (2008) dan Saleh (2003) yang melaporkan nilai duga heritabilitas yang tinggi pada jagung manis.

Nilai heritabilitas arti luas yang tinggi pada seluruh karakter kecuali jumlah baris biji dipengaruhi oleh hasil analisis ragam yang berbeda nyata. Nilai $F_{\text {hitung }}$ yang berbeda nyata disebabkan oleh nilai kuadrat tengah genotipe lebih besar daripada kuadrat tengah galat yang menghasilkan nilai ragam genetik independen (tidak dipengaruhi lingkungan) sehingga nilai heritabilitas arti luas menjadi tinggi (Piepho and Mohring, 2007). Hasil serupa juga terdapat pada penelitian Kashiani et al. (2010) dan Has and Has (2009).

Hasil korelasi genetik antar karakter (Tabel 4) menunjukkan tinggi tanaman memiliki korelasi yang signifikan dengan tinggi tongkol $(0,92)$, panjang tongkol $(0,82)$, bobot tongkol $(0,50)$ dan jumlah baris biji $(0,49)$. Hal tersebut mengindikasikan bahwa tanaman yang tinggi memiliki potensi hasil tongkol yang lebih baik dibandingkan dengan tanaman yang rendah. Hal ini diduga karena tanaman yang tinggi memiliki akumulasi bahan kering yang lebih tinggi yang dihasilkan oleh jumlah daun yang lebih banyak (Kashiani et al., 2010). Hasil penelitian serupa juga dilaporkan oleh Kashiani et al. (2008), Sujiprihati et al. (2003) dan Saleh et al. (2002b).

Bobot tongkol memiliki korelasi genetik yang signifikan (Tabel 4) dengan tinggi tanaman, tinggi tongkol, jumlah baris biji, panjang tongkol, dan diameter tongkol (masing-masing 0,50; 0,60; $0.51 ; 0,60$; dan 0,48 ). Hal ini menunjukkan bahwa bobot tongkol akan meningkat seiring dengan peningkatan karakter-karakter tersebut. Karakter panjang tongkol dan diameter tongkol memiliki pengaruh langsung yang tinggi terhadap bobot tongkol berdasarkan analisis lintasan pada Tabel 5 (masing-masing 0,585 dan 0,487).

Kedua karakter tersebut memiliki kontribusi positif secara langsung terhadap bobot tongkol. Seleksi untuk tujuan peningkatan bobot tongkol galur inbred dapat dilakukan pada kedua karakter tersebut karena nilai korelasi genetiknya mendekati nilai pengaruh langsungnya terhadap bobot tongkol. Hal ini sesuai dengan penjelasan Singh and Chaudary (1985) bahwa seleksi secara langsung akan efektif apabila koefisien korelasi antara faktor penyebab dan faktor efek nilainya mendekati nilai pengaruh langsungnya sehingga korelasi tersebut dapat menjelaskan hubungan yang sebenarnya. 
Tabel 3. Nilai kuadrat tengah genetik, F-hitung, ragam genetik, ragam fenotipe, heritabilitas arti luas, koefisien keragaman genetik dan simpangan baku ragam genetik karakter-karakter pada 20 galur inbred jagung manis

\begin{tabular}{lrrrrrrr}
\hline \multicolumn{1}{c}{ Karakter } & \multicolumn{1}{c}{$\mathrm{KT}_{\mathrm{Gx}}$} & \multicolumn{1}{c}{$\mathrm{F}_{\text {hitung }}$} & $\mathrm{KKG}(\%)$ & \multicolumn{1}{c}{$2 \sigma_{\mathrm{\sigma}}^{2}{ }_{\mathrm{Gx}}$} & \multicolumn{1}{c}{$\sigma_{\mathrm{Gx}}^{2}$} & \multicolumn{1}{c}{$\sigma_{\mathrm{Px}}^{2}$} & \multicolumn{1}{c}{$\mathrm{h}_{\mathrm{bs}}^{2}(\%)$} \\
\hline UJ & 40,78 & $14,44^{* *}$ & $\mathbf{8 , 5 3}$ & 8,40 & 12,65 & 13,59 & $\mathbf{9 3 , 0 8}$ \\
UB & 42,59 & $15,42^{* *}$ & $\mathbf{8 , 1 6}$ & 8,77 & 13,28 & 14,20 & $\mathbf{9 3 , 5 2}$ \\
TTan & 758,00 & $11,70^{* *}$ & $\mathbf{9 , 1 4}$ & 156,25 & 231,07 & 252,67 & $\mathbf{9 1 , 4 5}$ \\
TTk1 & 728,96 & $16,60^{* *}$ & $\mathbf{1 7 , 1 6}$ & 150,12 & 228,35 & 242,99 & $\mathbf{9 3 , 9 8}$ \\
JBB & 2,45 & $1,22^{\text {tn }}$ & 7.36 & 0,59 & 0,15 & 0,82 & 18,03 \\
JBPB & 13,95 & $3,49^{* *}$ & $\mathbf{1 1 , 3 0}$ & 2,93 & 3,32 & 4,65 & $\mathbf{7 1 , 3 2}$ \\
PT & 8,75 & $7,23^{* *}$ & $\mathbf{9 , 9 3}$ & 1,81 & 2,51 & 2,92 & $\mathbf{8 6 , 1 6}$ \\
DT & 2,70 & $2,91^{* *}$ & $\mathbf{3 0 , 1 9}$ & 0,57 & 0,59 & 0,90 & $\mathbf{6 5 , 6 9}$ \\
BT & 23386,05 & $16,80^{* *}$ & $\mathbf{3 1 , 0 5}$ & 4815,87 & 7331,38 & 7795,35 & $\mathbf{9 4 , 0 5}$ \\
PTT & 4,65 & $45,14^{* *}$ & $\mathbf{8 , 8 7}$ & 0,96 & 1,52 & 1,55 & $\mathbf{9 7 , 7 8}$ \\
\hline KT & & & & &
\end{tabular}

Keterangan: UJ: umur berbung jantan; UB: umur berbunga betina; TTan: tinggi tanaman; TTkl: tinggi tongkol; JBB: jumlah baris biji; JBPB: jumlah biji per baris; PT: panjang tongkol; Dt: diameter tongkol; BT: bobot tongkol; PTT: padatan total terlarut;**: berbeda nyata; tn: tidak berbeda nyata; $\mathrm{KT}_{\mathrm{Gx}}$ : kuadrat tengah genetik; $\sigma_{G x}^{2}$ : ragam genetik; $\sigma_{\sigma}^{2}$ Gx: simpangan baku ragam genetik; $\sigma_{\text {Px: }}^{2}$ ragam fenotipe; $h^{2}{ }_{b s}$ : heritabilitas arti luas; KKG: koefisien keragaman genetik; cetak tebal pada kolom $\mathrm{h}^{2}$ bs: heritablilitas tinggi; cetak tebal pada kolom KKG: keragaman genetik tinggi.

Tabel 4. Nilai koefisien korelasi antar karakter pada 20 galur inbred jagung manis

\begin{tabular}{|c|c|c|c|c|c|c|c|c|c|}
\hline Karakter & TTan & TTkl & JBB & JBPB & PT & DT & PTT & UB & UJ \\
\hline TTkl & $0,92^{* *}$ & & & & & & & & \\
\hline JBB & $0,49^{*}$ & $0,46^{*}$ & & & & & & & \\
\hline JBPB & $0,42^{\mathrm{ns}}$ & $0,40^{\mathrm{ns}}$ & $0,55^{*}$ & & & & & & \\
\hline PT & $0,82^{* *}$ & $0,89^{* *}$ & $0,42^{\mathrm{ns}}$ & $0,36^{\mathrm{ns}}$ & & & & & \\
\hline DT & $0,38^{\mathrm{ns}}$ & $0,39^{\mathrm{ns}}$ & $0,71^{* *}$ & $0,20^{\mathrm{ns}}$ & $0,21^{\mathrm{ns}}$ & & & & \\
\hline PTT & $0,24^{\mathrm{ns}}$ & $0,20^{\mathrm{ns}}$ & $-0,17^{\mathrm{ns}}$ & $-0,05^{\mathrm{ns}}$ & $0,49^{*}$ & $-0,45^{*}$ & & & \\
\hline UJ & $-0,01^{\mathrm{ns}}$ & $0,07^{\mathrm{ns}}$ & $0,20^{\mathrm{ns}}$ & $0,16^{\mathrm{ns}}$ & $0,03^{\mathrm{ns}}$ & $0,45^{*}$ & $-0,26^{\mathrm{ns}}$ & & \\
\hline UB & $-0,04^{\mathrm{ns}}$ & $0,02^{\mathrm{ns}}$ & $0,14^{\mathrm{ns}}$ & $0,16^{\mathrm{ns}}$ & $-0,02^{\mathrm{ns}}$ & $0,38^{\mathrm{ns}}$ & $-0,28^{\mathrm{ns}}$ & $0,92^{* *}$ & \\
\hline BT & $0,50^{*}$ & $0,60^{* *}$ & $0,51^{*}$ & $0,24^{\mathrm{ns}}$ & $0,60^{* *}$ & $0,48^{*}$ & $0,03^{\mathrm{ns}}$ & $-0,33^{\mathrm{ns}}$ & $-0,26^{\mathrm{ns}}$ \\
\hline
\end{tabular}

Keterangan : $* *$ signifikan pada $\mathrm{p}<0.01 ; *$ signifikan pada $\mathrm{p}<0.05 ; \mathrm{ns}=$ tidak signifikan; TTan: Tinggi Tanaman; TTkl: Tinggi Tongkol; JBB: Jumlah Baris Biji; JBPB: Jumlah Biji/Baris; PT: Panjang Tongkol; DT: Diameter Tongkol; PTT: Padatan Total Terlarut; DT: Umur Berbunga Jantan; UB: Umur Berbunga Betina; BT: Bobot Tongkol

Penggunaan analisis klaster ditujukan untuk mengelompokkan galur ke dalam beberapa kelas dengan kriteria pengelompokan berdasarkan pada ukuran kemiripan karakter yang dimiliki (Nisya, 2010). Kemiripan antar galur dapat diukur dengan menggunakan koefisien similarity, semakin besar nilai koefisien similarity antar galur menandakan semakin mirip galur tersebut (Mattjik dan Sumertajaya, 2011). Nilai 65,70\% - 100\% pada dendrogram (Gambar 1) menunjukkan skala berdasarkan koefisien similarity.
Galur-galur yang diuji terbagi menjadi tiga kelompok berdasarkan nilai koefisien similarity $70 \%$ (Gambar 1). Kelompok I terdiri atas galur E, K, Q, D, I, T, H, G, R, F, L, J, S dan C. Kelompok II terdiri atas galur B. Kelompok III tediri atas galur A, M, P, O, dan N. Galur-galur yang berada pada satu kelompok memiliki hubungan kemiripan yang besar sehingga kekerabatannya erat (Albrecht et al. 2010; Aguire dan Cabrera 2012). 
Tabel 5. Nilai koefisien lintasan pengaruh langsung dan tidak langsung beberapa karakter terhadap bobot tongkol

\begin{tabular}{ccccccccc}
\hline Karakter & Pengaruh & \multicolumn{5}{c}{ Pengaruh tidak langsung (PTL) } & Total & Korelasi \\
\cline { 3 - 6 } dibakukan & langsung & TTan & TTkl & JBB & PT & DT & PTL & Genotipe \\
\hline TTan & $-0,645$ & - & 0,006 & 0,006 & 0,006 & 0,005 & 0,023 & 0,502 \\
TTkl & 0,130 & 0,951 & - & 0,474 & $-0,037$ & 0,402 & 1,789 & 0,596 \\
JBB & 0,315 & 0,155 & 0,145 & - & 0,027 & 0,224 & 0,550 & 0,506 \\
PT & 0,585 & 0,222 & 0,066 & $-0,158$ & - & $-0,590$ & $-0,460$ & 0,599 \\
DT & 0,487 & $-0,596$ & $-0,317$ & $-0,273$ & $-0,245$ & - & $-1,430$ & 0,480 \\
\hline
\end{tabular}

Pengaruh sisa

0.490

Keterangan : TTan: Tinggi Tanaman; TTkl: Tinggi Tongkol; JBB: Jumlah Baris Biji; PT: Panjang Tongkol; DT: Diameter Tongkol

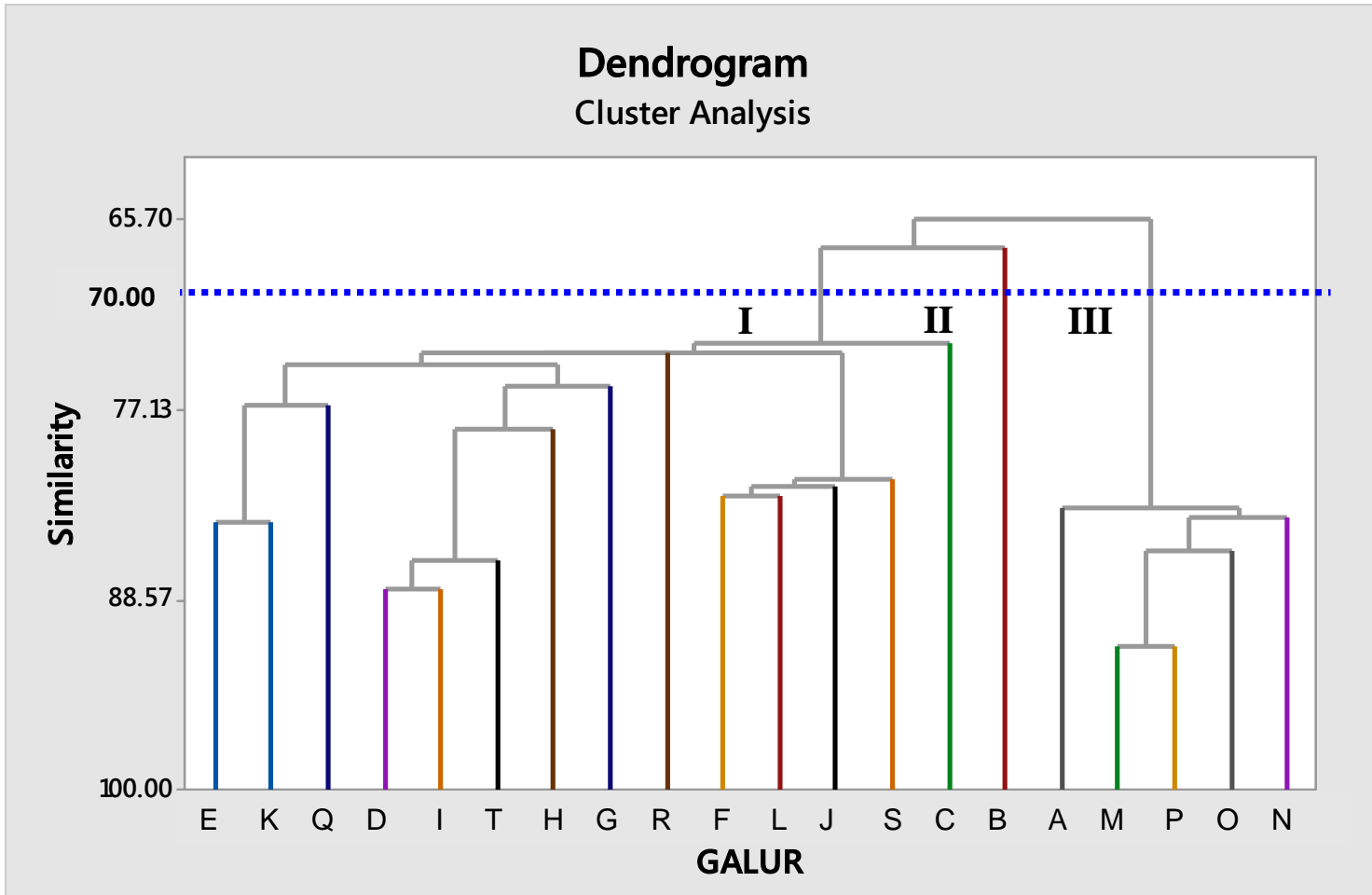

Gambar 1.Dendrogram pengelompokkan 20 galur inbred jagung manis pada nilai koefisien similarity $70 \%$ berdasarkan karakter kuantitatif.

Hasil pengelompokkan ini dapat menjadi referensi untuk menentukan galur inbred yang akan digunakan untuk tetua hibrida jagung manis. Pasangan tetua yang berasal dari kelompok yang berbeda atau kemiripannya terkecil berpotensi untuk menghasilkan hibrida dengan heterosis yang tinggi. Kelompok III memiliki koefisien similarity paling rendah terhadap kelompok lainnya. yaitu $65,70 \%$. Persilangan antara galur pada kelompok III dengan kelompok lain diduga memiliki potensi untuk mendapatkan tingkat heterosis yang tinggi pada hibrida yang dihasilkan. Hasil penelitian Suwarno et al. (2014) menjelaskan bahwa hibrida yang dihasilkan dari persilangan dua galur inbred yang berbeda kelompok heterotiknya memiliki heterosis yang tinggi dan jarak genetik antar tetua memiliki korelasi signifikan terhadap heterosis hibrida.

Kesimpulan penelitian ini yaitu terdapat keragaman genetik dan heritabilitas yang tinggi pada mayoritas karakter. Bobot tongkol berkorelasi genetik nyata dengan tinggi tanaman, tinggi tongkol, jumlah baris biji, panjang tongkol dan diameter tongkol. Karakter panjang tongkol dan diameter tongkol memiliki pengaruh langsung yang tinggi terhadap bobot tongkol. Analisis 
klaster menghasilkan tiga kelompok pada nilai koefisien similarity 70\%. Kelompok III memiliki koefisien similarity paling rendah terhadap kelompok lainnya yaitu $65,70 \%$. Persilangan antara galur yang terdapat pada kelompok III dengan kelompok lain memiliki potensi untuk mendapatkan tingkat heterosis yang tinggi pada hibrida yang dihasilkan.

\section{UCAPAN TERIMA KASIH}

Penulis mengucapkan terima kasih kepada ibu Ani dan PT. Agro Nusantara Prima yang telah mengizinkan koleksi galur-galur inbred-nya digunakan dalam penelitian ini.

\section{DAFTAR PUSTAKA}

Aguirre NC and Cabrera FAV. 2012. Evaluating the fruit production and quality of cherry tomato (Solanum lycopersicum var. cerasiforme). Rev. Fac. Nal. Agr. Medellin 65(2):6593-6604.

Albrecht E, Escobar M, Chetelat RT. 2010. Genetic diversity and population structure in the tomato-like nightshades Solanum lycopersicoides and S. sitiens. Annals of Botany 105:535-554.

Badan Pusat Statistik [BPS]. 2015. Luas Panen Jagung 2014. Tersedia pada: http://www.bps.go.id/site/resultTab. [Diakses: 13 April 2015].

Bahar H, Zen S. 1993. Parameter genetik pertumbuhan tanaman, hasil dan komponen hasil jagung. Zuriat 4:4-7.

Has V , Has I. 2009. Genetic inheritance of some important character of sweet corn. Not. Bot. Hort. Agrobot. Cluj 37 (1): 244-248.

Hallauer AR, Carena MJ, Miranda FJB. 2010. Quantitative Genetics in Maize Breeding. Iowa (US) : Iowa State University Press

Iriany, R.N., S. Sujiprihati, M. Syukur, J. Koswara, M. Yunus. 2011. Evaluasi daya gabung dan heterosis lima galur jagung manis (Zea mays var. saccharata) hasil persilangan dialel. J. Agron. Indonesia 39:103- 111.

Kashiani P, Saleh G, Abdullah SN, Abdulah NAP. 2008. Performance, heritability and correlation studies on nine advanced sweet corn inbred lines. Proceeding of the $10^{\text {th }}$ Symposium of Malaysian Society of Applied Biology, Nov. 6-8, Malaysia.

Kashiani P, Saleh G, Abdullah NAP, Abdullah SN. 2010. Variation and genetic studies in selected sweet corn inbred lines. Asian Journal of Crop Science 2(2):78-84.

Kementerian Pertanian [Kementan]. 2015. Data Produksi Jagung Manis 2014. Tersedia pada:

http://aplikasi.pertanian.go.id/bdsp/hasil ko m.asp. [Diakses: 13 April 2014].

Mattjik AA, Sumertajaya IM. 2011. Sidik Peubah Ganda dengan Menggunakan SAS. Bogor (ID): Institut Pertanian Bogor. Mayo O. 1987. The Theory of Plant Breeding. $2^{\text {nd }}$ Edn. Oxford University Press, New York (US).

Nisya FN. 2010. Analisis keragaman genetik jarak pagar (Jatropha curcas L.) berdasarkan karakter morfologi, agronomi dan marka RAPD [tesis]. Bogor (ID): Institut Pertanian Bogor.

Pabendon M, Mejaya MJ, Koswara J, Aswidinnoor H. 2007. Analisis keragaman genetik inbrida jagung berdasarkan marka SSR dan korelasinya dengan data fenotipik F1 hasil silang uji. Penelitian Pertanian Tanaman Pangan. 26: 69-77.

Piepho H and Möhring J. 2007. Computing Heritability and Selection Response from Unbalanced Plant Breeding Trials. Genetics; 177(3): 1881-1888.

Pinaria A, Baihaki A, Setiamiharja R, Daradjat AA. 1995. Variabilitas genetik dan heritabilitas karakter-karakter biomassa 53 genotipe kedelai. Zuriat 6(2):88-92.

Rifianto A, Syukur M, Trikoesoemaningtyas, Widodo. 2013. Daya gabung hasil dan kompenen hasil tujuh galur jagung manis di dua lokasi. J.agron. Indonesia 41(3):235241.

Ruswandi D, Basuki MM, Annissa, Ruswandi S, Rostini N. 2006. Daya gabung galur-galur downy mildew resistance (DMR) dan quality protein maize (QPM) berdasarkan analisis line $x$ tester. Zuriat. 17: 25-34.

Saleh G, Panjaitan K, Anuar AR, Mihdzar AK. 2001. Heterosis, combining ability and heritability studies in grain maize hybrids. UPM Reserch Report 2001. Faculty of Agriculture, pp: 19-21.

Saleh G, Abdullah D, Anuar AR. 2002a. Effects of location on performance of selected tropical maize hybrids development in Malaysia. Pertanika J. Trop. Agric. Sci., 25: 75-86.

Saleh GB, Abdullah D, Anuar AR. 2002b. Performance, heterosis and heritability in 
selected tropical maize single, double, and three-way cross hybrids. J. Agric. Sci., 138: 21-28.

Saleh G. 2003. Grain maize and sweet corn production guidelines. University Putra Malaysia. Serdang.

Sigh RK, Chaudhary BD. 1985. Biometrical Methods in Quantitative Genetic Analysis. New Delhi (IN): Kalyani.

Sleper DA, Poehlman JM. 2006. Breeding Field Crops. $5^{\text {th }}$ Edn., Wilwy-Blackwel Publ. (US).

Stoskopf NS, Tomes DT, Christie BR. 1993. Plant Breeding Theory and Practice. Westview Press Inc., San Fransisco (US).

Sujiprihati S, Saleh G, Ali ES. 2003. Heritability, performance and correlation studies in single cross hybrid on tropical maize. Asian J. Plant Sci., 2 : 51-57.

Sujiprihati S, Syukur M, Makkulawu AT, Iriany PN. 2014. Perakitan varietas hibrida jagung manis berdaya hasil tinggi dan tahan terhadap penyakit bulai. J. Ilmu Pertanian Indonesia 17(3):159-165.

Suwarno WB, Pixley KV, Palacios-Rojas N, Kaeppler SM, and Babu R. 2014. Formation of heterotic groups and understanding genetic effects in a provitamin A biofortied maize breeding program. Crop Science 54: 14-24. 